\title{
Thematic Progression in Economic Discourse: A Case Study of the English-Chinese Reports from The Economist
}

\author{
Li Fan ${ }^{1} \&$ Wenbo Ma ${ }^{1}$ \\ ${ }^{1}$ Central University of Finance and Economics, China \\ Correspondence: Li Fan (Ph. D / Professor), School of Foreign Studies, Central University of Finance and \\ Economics (CUFE), Beijing, 102206, China. E-mail: fansong_cn@yahoo.com
}

Received: September 24, 2021

Accepted: November 8, $2021 \quad$ Online Published: December 1, 2021

doi:10.5539/ijel.v12n1p86

URL: https://doi.org/10.5539/ijel.v12n1p86

\begin{abstract}
The patterns of thematic progression, greatly influenced by culture-peculiar thinking patterns and language-particular features, reflect the integration of form and meaning in the flow of information in discourse. The economic discourse has its distinct linguistic characteristics and important communicative purposes. Thus, related research on the thematic progression of economic discourse is important for us to understand the language use in the context of economic and financial activities and also has important implications for language learning and teaching, translation, automated language information processing etc. This study first employs CiteSpace, a document visualization tool, to review the existing related studies on the economic discourse in China, and then analyzes the major patterns of thematic progression in the economic discourse based on the English and Chinese reports from The Economist. Through our discussion, we aim to explore universals and peculiarities of thematic progression in English-Chinese economic discourse and discuss the reasons attributing to major distinctions between the two languages in terms of thematic progression.
\end{abstract}

Keywords: CiteSpace, thematic progression, theme-rheme, economic discourse

\section{Research Background}

\subsection{Studies on the Thematic Progression}

The "Theme" and "Rheme" are mainly derived from the Prague school of functional linguistics and Halliday's systemic functionalism. The "Theme" is what the proposition talks about, i.e., old information, a point of departure; the "Rheme" is what is talked about in relation to the "Theme", i.e., new information, an expansion of the discourse (e.g., Mathesius, 1929; Firbas, 1964; Halliday, 1967, 1994; Daněs, 1970; Prince, 1979, 1981; Hajicovă, 1986; Halliday \& Matthiessen, 1994; Lambrecht, 1994).

"Thematic progression" was proposed by Daněs $(1970,1974)$, who argued that thematic progression establishes connections between sentences in discourse according to the relationship between the current theme and the previous theme. The formulation of the theory of thematic progression has expanded the perspective of language studies beyond the boundary of sentence to the domain of discourse, from the view of the cohesiveness of form and meaning.

The classification of thematic progression patterns has differences in different scholars' doctrines, but the core forms and categories are common. For example, in Daněs proposed four patterns, i.e., simple linear progression, constant progression, derived hyperthematic progression, and splitting progression while Eggins proposed three patterns, i.e., theme reiteration, zig-zag theme pattern, and multiple-theme pattern, but there are primary commonalities between the two classifications. The scholars in China (e.g., Hu, 1982, 1984, 1994; Xu, 1982, 1985; Huang, 1985; Huang, 1988; Qi, 1993; Zhu, 1995) have also discussed some thematic progression patterns.

Discourse is a complex system of form and meaning, so thematic progression patterns are not always simply and individually used in discourse; most patterns in discourse are combinations of various patterns.

The study of the thematic progression patterns has multiple meanings, demonstrating the integration of form and meaning, exploring the influence of cultural awareness and thinking patterns on discourse organization, and having important implications for a great variety of studies, such as metalinguistic research, language learning and teaching research, translation research, automated language information processing, and artificial intelligence research. 


\subsection{Studies on Stylistic Features and Thematic Progression Patterns in China}

The theme-rheme theory was introduced into China in the 1980's. For an outline of its development in China, we make a literature review of the existing related Chinese studies in CNKI (China National Knowledge Infrastructure) with CiteSpace. CNKI (https://www.cnki.net/) is the largest research database and the most widely used tool by academics in China. CiteSpace is a free Java application that analyzes and visualizes research patterns and trends in the selected literature by identifying turning points and key points in these studies (https://citespace.podia.com/, Chen, 2004). In the CNKI database of Chinese academic journals, we searched for “主述位” (“theme-rheme”) as the target term and obtained 1013 related papers. In the following, we analyze the research hotspots and trends with CiteSpace and detect gaps in the research on the economic discourse. From the keyword chronology diagram (Figure 1) based on the keywords appearing in the studies on thematic progression and the list of top keywords with the strongest citation bursts in these studies in Figure 2, it can be seen that the research of thematic progression in China mainly focuses on the research of discourse cohesiveness information structure, and teaching of foreign language writing and translation.

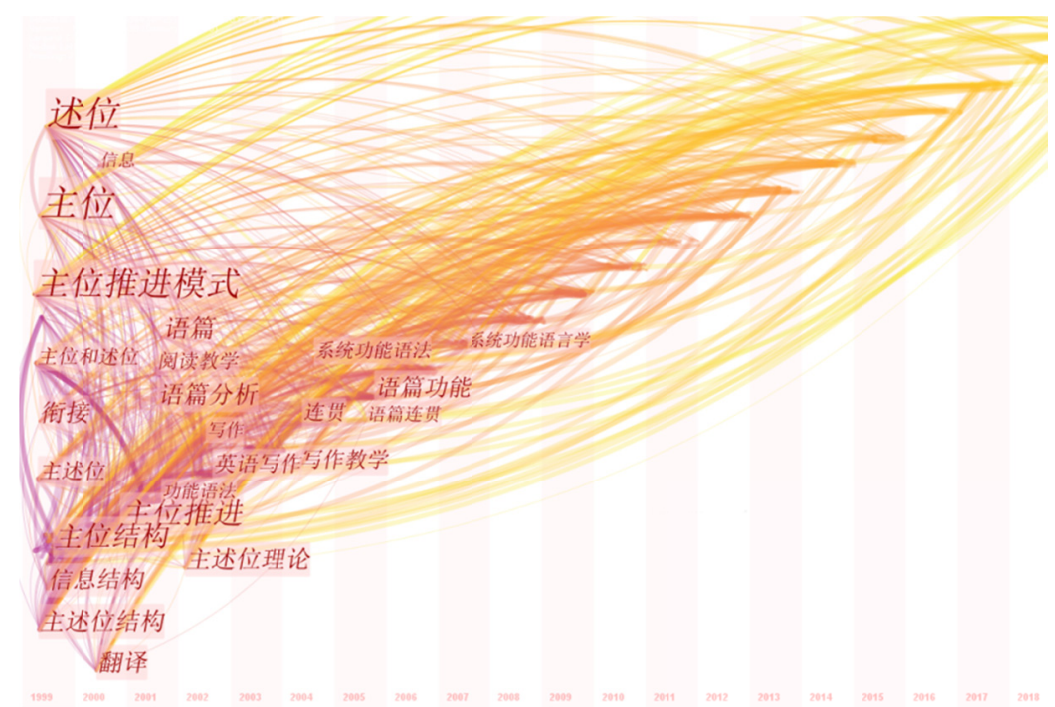

Figure 1. Keyword chronology diagram based on the studies on thematic progression in China

Note. The English translations of the keywords in the diagram are given here: 1. 主位: theme; 2. 述位: rheme; 3. 主位推进模式: thematic progression pattern; 4. 主位结构: thematic structure; 5. 信息结构: information structure; 6. 衔接: convergence; 7. 连贯: cohesiveness; 8 . 语篇: discourse; 9. 语篇分析: discourse analysis; 10. 阅读教学: reading instruction; 11. 写作: writing; 12. 翻译: translation; 13. 系统功 能语法: Systematic Functional Grammar; 14. 功能语法: functional grammar.

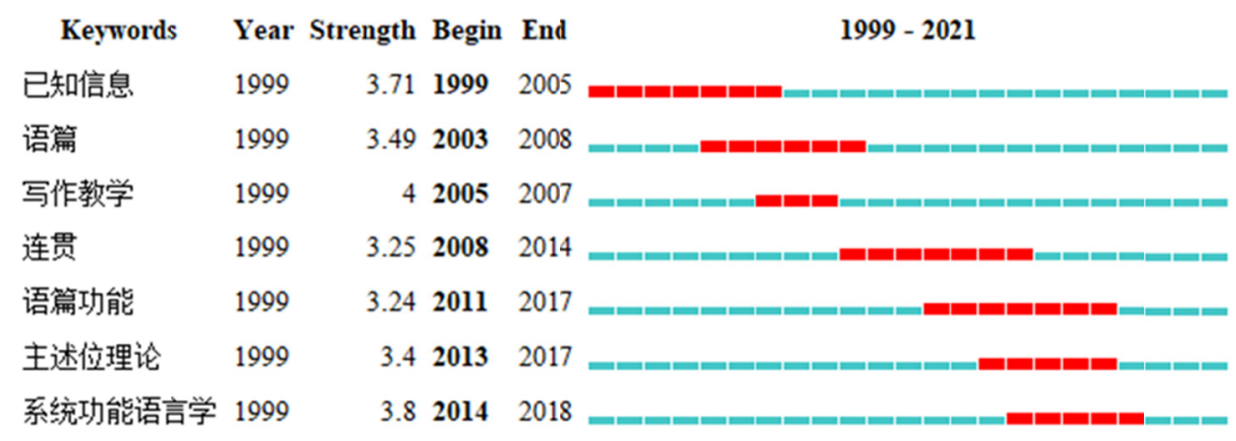

Figure 2. 7 Keywords with the Strongest Citation Bursts

Note. The English translations of the keywords in the figure, arranged from the top to the bottom, are given here : 1 . 已知信息: known information; 2. 语篇: discourse; 3. 写作教学: writing instruction; 4. 连贯: cohesiveness; 5. 语篇功能: discourse function; 6. 主述位理论: theme-rheme theory; 7. 系统功能语言学: Systematic Functional Linguistics. 
Previous studies (e.g., Fries, 1983; Francis, 1990; Nwogu \& Bloor, 1991) have proved that there is a correlation between the choice of thematic progression patterns and the genre of the discourse. The same conclusion has been reached in related studies in China, for example, studies on literary discourse, such as $\mathrm{Li}$ (2003) and Zhang (2005); studies on journalistic discourse, such as Liu et al. (2014), Cao and Li (2021), Bi (2014); studies on legal discourse, such as Dong (2010), Huang and Hu (2014), Shi et al. (2018); studies on scientific and technical discourse, such as Shen (1999), Yu (2002), Chen (2006), Shen (2021); studies on medical discourse, such as Chen (2011); the studies on political discourse, such as You (2013), Guo (2013), You (2013). There are also some studies on thematic progression of economic discourse, but the number is relatively small. Among the available literature, Wang (2010) found more unmarked patterns of thematic progression than marked ones used in Chinese economic news. Based on the English corpus, Xue (2007) proposed that the most common pattern of thematic progression in business news is subject-identity type (classified as "the parallel progression pattern" in this study), which has the same theme in each sentence. Also based on English data, Li and Yang (2012) reported that the most frequently used patterns in financial news texts are subject-identity and constant patterns because the subject-identity pattern can be handily used for a description of the same event in depth. By using the constant pattern, the theme of the later sentence summarizes the previous sentence or continues the discussion on the topic of the previous sentence by introducing new information. From these studies, it can be seen that economic texts have their own distinctive patterns of thematic progression; the most used pattern is the subject-identity pattern (classified as "the parallel progression pattern" in this study).

As stated above, there is still a lot of room for improvement in domestic research on the thematic progression of the Chinese economic discourse and its comparison with the discourse in other languages. Here are two reasons for carrying on the research in this field. First, there is the lack of current studies. As seen from the list of keywords in the current studies on the thematic progression of economic discourse in Table 1, keywords related to economy and business appear less, and are less central in the set of the previous literature in our analysis.

Table 1. List of keywords in the studies on thematic progression in economic discourse (partial)

\begin{tabular}{lllll}
\hline Serial number & Keywords & Frequency & Centrality & Year of the first occurrence in the literature \\
\hline 1 & Introduction to Corporate English & 1 & 0.00 & 2012 \\
2 & Foreign trade correspondence & 1 & 0.00 & 2014 \\
3 & Business English & 1 & 0.00 & 2019 \\
4 & Business Language & 1 & 0.00 & 2020 \\
5 & English Corporate Profile & 1 & 0.00 & 2021 \\
6 & Chinese Corporate Profile & 1 & 0.00 & 2021 \\
\hline
\end{tabular}

On the other hand, existing studies are mainly based on a monolingual corpus, and there is a lack of research from the perspective of cross-linguistic comparison. Therefore, this study will discuss the issue of thematic progression of economic discourse using some English reports in The Economist and Chinese translation as bilingual data, aiming to answer these questions: a) What are the characteristics of thematic progression in economic discourse in English and Chinese? b) What strategies of translation are needed if there exists some difference between the two languages?

\section{Research Framework}

In previous studies, different scholars have elaborated on the thematic progression patterns and made different classifications. In this paper, we adopt the classification by Xu (1982), which involves thematic parallel, continuity, concentration, and intersectional progression. The specific definitions are given as follows.

(1) Parallel progression pattern: After the first sentence in the parallel pattern clarifies the main theme, each subsequent sentence takes it as its theme and introduces a different rheme to explain the theme from different perspectives, as shown below (The pictures illustrating thematic progression patterns in this study are made according to Sheng-Huan $\mathrm{Xu}, 1982)$ :

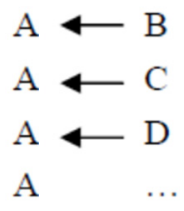


(2) Constant progression pattern: In the constant progression pattern, the rheme of the preceding sentence becomes the theme of the following sentence, illustrated as follows:

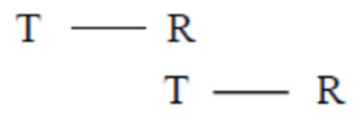

(3) Concentrating progression pattern: After the first sentence clarifies a rheme, it is used as the rheme in subsequent sentences which have different themes. That is, it happens like that the starting point of each sentence is different, but they all focus on one ending point. The pattern can be demonstrated in the way:

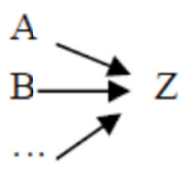

(4) Intersectional progression pattern. In the intersectional progression pattern, the theme of the previous sentence becomes the rheme of the next sentence, which happens in this intersectional pattern to form an intricate relationship among sentences in the flow of information. Such complexity in the flow of information can be made clear in the following way:

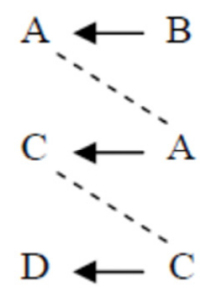

We adopt Xu's (1982) classification as our analysis framework because it integrates the core ideas of the classical models proposed before it, and secondly, it is based on the Xu's profound grasp of similarities and differences between English and Chinese. It has also gained practical validity in some studies devoted to the analysis of language phenomena, for example, Weng (2011) used Xu's classification to examine 100 news reports and found that the classification method worked well in accounting for the basic patterns of thematic progression. In the following section, we will use these four patterns to analyze English reports and their Chinese translations collected from The Economist with the aim of exploring dominant thematic progression patterns of English and Chinese economic discourse.

\section{Case Study}

\subsection{Use of the Parallel Progression Pattern}

First, the parallel progression pattern in (1) is examined:

(1) (a) English text: Their visions are communicated by a simple narrative. Amazon's is a focus on customer satisfaction, behind which employees, suppliers and shareholders fall into line. Blue Origin's core belief is that reusable rockets will lower costs so that access to space is made possible for many. (Jeff Bezos's final frontier, Where is Amazon's boss headed next? Schumpeter, The Economist, 2020, 11. https://www.businessreview.global/zh-CN/latest/5fa557c961cb4179de002cca?token=ce66d59a85d8cc0de34567 15f136ef50f423e303)

(b) Chinese translation: 首先, 两家公司的愿景都以一套简单的叙事来传达。亚马逊的愿景是关注客户满 意度, 这一点得到了员工、供应商和股东的一致认同。蓝色起源的核心信念是可重复使用的火箭会降低 成本, 这样很多人就有机会进入太空。

Table 2. The thematic analysis of the English text in (1)

\begin{tabular}{lll}
\hline No. of sentences & Theme & Rheme \\
\hline $\mathbf{1}$ & Their visions & are communicated by a simple narrative. \\
$\mathbf{2}$ & Amazon's & is a focus on customer satisfaction, behind which employees, suppliers and shareholders \\
& fall into line. \\
$\mathbf{3}$ & Blue Origin's core belief & is that reusable rockets will lower costs so that access to space is made possible for many. \\
\hline
\end{tabular}


In the English original, the themes of the second and third sentences, "Amazon's (vision)" and "Blue Origin's core beliefs", are specific examples of the theme of the first sentence, "Their visions", and thus the three noun phrases have the same reference, carrying on specific discussion about the "vision". On the whole, this discourse shows a typical pattern of parallel progression.

Table 3. The thematic analysis of the Chinese translation in (1)

\begin{tabular}{lll}
\hline No. of sentences & Theme & Rheme \\
\hline $\mathbf{1}$ & 两家公司的愿景 & 都以一套简单的叙事来传达 \\
& Their visions (of the two companies) & are communicated by a simple narrative \\
$\mathbf{2}$ & 亚马逊的愿景 & 是关注客户满意度, \\
& Amazon's & is a focus on customer satisfaction \\
& 这一点(关注客户满意度) & 得到了员工、供应商和股东的一致认同 \\
& this point (customer satisfaction) & behind which employees, suppliers and shareholders fall into line \\
$\mathbf{3}$ & 蓝色起源的核心信念 & 是可重复使用的火箭会降低成本, 这样很多人就有机会进入太空 \\
& Blue Origin's core belief & is that reusable rockets will lower costs so that access to space is made \\
& & possible for many. \\
\hline
\end{tabular}

In the Chinese translation, “两家公司的愿景” (“the vision of the two companies”), “亚马逊的愿景” (“Amazon's vision”) and “蓝色起源的核心信念” (“Blue Origin’s core beliefs”) also appear as themes as in the English original. In the Chinese translation, the repetition of the noun “愿景” (“vision”) appears in “亚马逊的愿 景” (“Amazon's”), firstly, because there is no the same pattern of omission in Chinese as in English, and secondly, it can make the message clearer. In addition, in the Chinese translation, when expressing the content of the relative clause in the second sentence of the original text, since the Chinese language does not have the same syntactic structure, the translator adopts the way of using "this point" as the theme, which refers back to the content expressed by Amazon's, forming a constant progression pattern here. Such a change in Chinese translation shows the effect of English-Chinese differences on the adoption of theme progression patterns, and moreover, the discourse makes the use of the thematic progression patterns flexible and very often more than one pattern are blended to the discourse more informative.

(2) (a) English text: These efforts, however valiant, are in their infancy. They may not amount to anything unless governments, too, weigh in as they have done with the European Union's General Data Protection Regulation, and the California Consumer Privacy Act. (Free the data serfs! The fight back against big tech's feudal lords has begun, Schumpeter, The Economist, 2020,2 https://www.businessreview.global/zh-CN/latest/5f9b7d1c61cb417f7a0b9a4d?token=0a9bb9962987ef87872d66 449ba35378f41536e5)

(b) Chinese translation: 这些努力不管有多坚决，也都还处在起步阶段。而且除非政府也参与其中，否则 可能无所作为。欧盟的《通用数据保护条例》(GDPR) 和美国的《加州消费者隐私法案》(CCPA) 就是 政府参与的结果。

Table 4. The thematic analysis of the English text in (2)

\begin{tabular}{lll}
\hline No. of sentences & Theme & Rheme \\
\hline $\mathbf{1}$ & These efforts & however valiant, are in their infancy \\
$\mathbf{2}$ & They (the efforts) & may not amount to anything \\
$\mathbf{3}$ & governments & weigh in \\
$\mathbf{4}$ & they (governments) & have done with the European Union's General Data Protection Regulation, and the \\
& & California Consumer Privacy Act. \\
\hline
\end{tabular}

First, the English text presents two parallel patterns of thematic progression, where the main positions are: "These efforts/They" (the efforts) and "governments/they (governments)". 
Table 5. The thematic analysis of the Chinese translation in (2)

\begin{tabular}{|c|c|c|}
\hline No. of sentences & Theme & Rheme \\
\hline \multirow[t]{2}{*}{1} & 这些努力 & 不管有多坚决, 也都还处在起步阶段 \\
\hline & These efforts & however valiant, are in their infancy \\
\hline \multirow[t]{2}{*}{2} & 政府 & 除非也参与其中 \\
\hline & governments & (unless) weigh in \\
\hline \multirow[t]{2}{*}{3} & (这些努力) & 否则可能无所作为 \\
\hline & They (the efforts) & may not amount to anything \\
\hline \multirow[t]{2}{*}{4} & the European Union's General Data Protection & 就是政府参与的结果 \\
\hline & $\begin{array}{l}\text { Regulation, and the California Consumer Privacy Act } \\
\text { 欧盟的《通用数据保护条例》(GDPR) 和美国的《加 } \\
\text { 州消费者隐私法案》(CCPA) }\end{array}$ & (the results of governments) \\
\hline
\end{tabular}

In the Chinese translation, first, the unless clause is moved to the head of the Chinese translation from the main clause in the English original, which is an important position for such sentences to express emphasis. Secondly, the theme in Sentence 4 has been changed. In the original English, "they (governments)" are in the position for theme, and the completed regulations and bills are in the position for rheme, and the structure of the whole sentence is light in the head and heavy in the end. Thus, the first sentence and the third sentence form a pattern of parallel thematic progression. From this example, it can be seen that such language-particular characteristic, i.e., that of placing the parts expressing hypothetical conditions or the parts having much length in Chinese, can lead to a change in the thematic progression patterns in English to Chinese translation.

\subsection{Use of the Constant Progression Pattern}

The use of the constant progression pattern is illustrated in (3):

(3) (a) English text: Before becoming President, Mr. Trump spent much of his money on golf courses, hotels and other trophy assets that the Times says have since racked up huge tax losses. Thanks to that red ink, it said he paid a mere $\$ 750$ in federal income taxes in both 2016, the year he was elected, and his first year in office- and not a cent in ten of the previous 15 years. (All the president's moolah, How good a businessman is Donald Trump? Schumpeter, The Economist, 2020,11) (https://www.businessreview.global/zh-CN/latest/5f83b8d061 cb4114723e0538?token=1deee03716e3ab3f3b60ec 9f89d98c83a98aee06)

(b) Chinese translation: 在成为总统之前, 特朗普把大部分钱都花在了高尔夫球场、酒店和其他炫耀性资 产上。《纽约时报》称, 这些资产之后造成了巨大的税收流失。该报称, 拜这些资产的亏损所赐, 特朗普 在他当选的 2016 年和上任的第一年都只缴纳了 750 美元的联邦所得税, 而在此前的 15 年中, 有 10 年他 一分钱也没缴过。

Table 6. The thematic analysis of the English text in (3)

\begin{tabular}{lll}
\hline No. of sentences & Theme & Rheme \\
\hline 1 & Mr. Trump & $\begin{array}{l}\text { spent much of his money on golf courses, hotels and other trophy assets } \\
\text { (that the Times says) have since racked up huge tax losses }\end{array}$ \\
3 & It (the Times) & $\begin{array}{l}\text { said he paid a mere } \$ 750 \text { in federal income taxes in both 2016, the year he was } \\
\text { elected, and his first year in office-and not a cent in ten of the previous } 15 \text { years }\end{array}$ \\
\hline
\end{tabular}

In the first and second sentences, the theme of the first sentence is "Mr. Trump", and the theme of the second sentence is "his assets", which is in the rheme in the first sentence. In the second sentence, "the Times" appears in the parenthesis, and in the third sentence it becomes the theme, which forms a parallel pattern of thematic progression. 
Table 7. The thematic analysis of the Chinese translation in (3)

\begin{tabular}{lll}
\hline No. of sentences & Theme & Rheme \\
\hline 1 & 特朗普 & 把大部分钱都花在了高尔夫球场、酒店和其他炫耀性资产上 \\
& Mr. Trump & spent much of his money on golf courses, hotels and other trophy assets \\
2 & 《纽约时报》 & 称这些资产造成了巨大税收流失 \\
& the Times & have since racked up huge tax losses \\
& 该报 & 称拜这些资产的亏损所赐, 特朗普在他当选的 2016 年和上任的第一年都只缴纳了 750 \\
& It (the Times) & 美元的联邦所得税, 而在此前的 15 年中, 有 10 年他一分钱也没缴过 \\
& said he paid a mere $\$ 750$ in federal income taxes in both 2016, the year he was elected, and \\
& his first year in office一-and not a cent in ten of the previous 15 years \\
\hline
\end{tabular}

The Chinese translation shows a change in the thematic progression pattern: the progression pattern lying between the first and second sentences in the English text disappears, and a parallel pattern is formed between the second and the third sentences. The reason for this change should be that Chinese people are accustomed to saying the source of information before the content of information in the reporting language.

\subsection{Use of the Concentrative Progression Pattern}

Example (4) is used to illustrate the use of the concentrative progression pattern:

(4) (a) English text: (As he wrote in 2015,) Amazon and AWS may look different, but they share similar underlying principles on which they act. The same may be true of Amazon and Blue Origin. (Jeff Bezos's final frontier, Where is Amazon's boss headed next? Schumpeter, The Economist, 2020, 11) (https://www.businessreview.global/zh-CN/latest/5fa557c961 cb4179de002cca?token=ce66d59a85d8cc0de34567 $15 \mathrm{f} 136 \mathrm{ef} 50 \mathrm{f} 423 \mathrm{e} 303$ )

(b) Chinese translation: (正如他在 2015 年写道的) 亚马逊和 AWS 看起来可能不同, 但它们遵循相似的基 本运作原理。蓝色起源和亚马逊可能也是这样。

Table 8. The thematic analysis of the English text in (4)

\begin{tabular}{lll}
\hline No. of sentences & Theme & Rheme \\
\hline 1 & Amazon and AWS & may look different \\
2 & they & share similar underlying principles on which they act \\
3 & The same & may be true of Amazon and Blue Origin. \\
\hline
\end{tabular}

In the original English text, a concentrative thematic progression pattern is used between Sentences 1-2 and Sentence 3, the themes different and the rheme unchanged, which refers to "may look different but share similar underlying principles on which they act"; in addition, a parallel progression pattern is formed between Sentences 1 and 2, "the Amazon and AWS" and "they" refer to the same identity.

Table 9.

\begin{tabular}{lll}
\hline No. of sentences & Theme & Rheme \\
\hline $\mathbf{1}$ & 亚马逊和 AWS & 看起来可能不同 \\
& Amazon and AWS & may look different \\
$\mathbf{2}$ & 它们 & 遵循相似的基本运作原理 \\
& they & share similar underlying principles on which they act \\
$\mathbf{3}$ & 蓝色起源和亚马逊 & 可能也是这样 \\
& Amazon and Blue Origin & may be the same \\
\hline
\end{tabular}

In the Chinese translation, a concentrative progression pattern is used between Sentences 1,2 and 3. The themes of the two sentences are different, i.e., “亚马逊和 AWS” (“Amazon and AWS”) in Sentences 1 and 2 and “蓝色 起源和亚马逊” (“Amazon and Blue Origin”) in Sentence 3, and rhemes, although different in form, are the same in meaning, i.e., “看起来可能不同, 遵循相似的基本运作原理” (“may look different” and “follow similar basic operating principles"). In addition, a parallel pattern of thematic progression is formed between Sentence 1 and Sentence 2, where “亚马逊和 AWS" (“Amazon and AWS”) and “它们” (“they”) have the same reference. 


\subsection{Use of the Intersectional Progression Pattern}

The intersectional progression composes a more intricate relationship, as illustrated as in (5):

(5) (a) English text: The use of data, after all, is now the world's biggest business. Some $\$ 1.4$ trn of the combined \$1.9trn market value of Alphabet (the owner of Google) and Facebook, comes from users' data and the firms' mining of it, ... (Free the data serfs! The fight back against big tech's feudal lords has begun, Schumpeter, The Economist, 2020 , https://www.businessreview.global/zh-CN/latest/5f9b7d1c61cb417f7a0b9a4d?token=0a9bb9962987ef87872d66 449ba35378f41536e5)

(b) Chinese translation: 毕竟, 对数据的使用是当今世界上最大的买卖。在 Alphabet (谷歌的母公司) 和 Facebook 合计 1.9 万亿美元的市值中，.... 大约有 1.4 万亿都来自用户数据以及对数据的挖掘。

Table 10. The thematic analysis of the English text in (5)

\begin{tabular}{lll}
\hline No. of sentences & Theme & Rheme \\
\hline $\mathbf{1}$ & $\begin{array}{l}\text { The use of data } \\
\mathbf{2}\end{array}$ & $\begin{array}{l}\text { Some } \$ 1.4 \text { trn of the combined } \$ 1.9 \text { trn market value world's biggest business } \\
\text { of Alphabet (the owner of Google) and Facebook }\end{array}$ \\
\hline
\end{tabular}

Table 11. The thematic analysis of the Chinese translation in (5)

\begin{tabular}{lll}
\hline No. of sentences & Theme & Rheme \\
\hline $\mathbf{1}$ & 数据的使用 & 是当今世界上最大的买卖 \\
& The use of data & is now the world's biggest business \\
$\mathbf{2}$ & (在 Alphabet (谷歌的母公司) 和 Facebook 合计 1.9 万 & $\begin{array}{l}\text { 都来自用户数据以及对数据的挖掘 } \\
\text { comes from users' data and the firms' mining } \\
\end{array}$ \\
& 亿美元的市值中..., 大约有 1.4 万亿 & of it \\
& Some $\$ 1.4$ trn of the combined $\$ 1.9$ trn market value of \\
& Alphabet (the owner of Google) and Facebook & \\
\hline
\end{tabular}

In this example, both the English original and the Chinese translation reflect the use of the intersectional progression pattern. The theme of the first sentence is "The use of data", which is placed at the end of the second sentence and becomes the rheme.

\section{Conclusion}

The above discussion reveals the prominent patterns which are widely applied in the economic discourse of English and Chinese, i.e., the patterns of parallel progression, constant progression, concentrative progression and intersectional progression. Besides, what the two languages have in common also lies in a common trend in the use of the thematic progression patterns of English-Chinese economic discourse: the flexible use of multiple patterns under the premise of the clear and informative exchange of information. Aside from the sameness, on the other hand, our study also reflects the fact that there are some cross-linguistic differences between English and Chinese when thematic patterns are concerned. Such differences are mainly attributed to these factors determining the choice of thematic progression patterns:

First of all, the choice of thematic progression patterns is related to the mode of thinking. English often puts the point of observation or narration on the result or the bearer of an action and takes it as the subject of the sentence; Chinese often focuses on the specific person as the doer of an action first and then on what he or she does, and the subject of the sentence is mostly the noun denoting a person undertaking an action (e.g., Yang, 2008). In (3), for example, the English original focuses on the content of the report and presents the reporter only as a parenthesis, but in the Chinese translation the reporter is put in front as theme, reflecting the focus on the action performer in the way of thinking.

Secondly, the choice of thematic progression patterns is also related to the typological feature that English is subject-oriented and Chinese is topic-oriented, as pointed out by Wang (2009), Du (2004) and Yang (2008). For example, in (1), the topic-oriented Chinese directly has "this point" at the beginning of the sentence, which makes the thematic progression pattern of the Chinese translation different from that of the original English text.

Thirdly, the choice of thematic progression patterns also reflects the way the elements in a sentence are combined, i.e., Chinese reflects the combination of the elements in a sentence by means of meaning while English creates such a combination with connective words, which is also found in the studies such as Deng 
(2007), Zhang and Li (2017), Du (2004).

Fourth, the choice of thematic progression patterns also shows the effect of the characteristics of linear arrangement of words at the head and end of the sentence, with English following the end-heavy principle and Chinese having the head-heavy principle, as discussed in Du (2004). This cross-linguistic difference leads to the variation of the linguistic units in subject position as seen in (2). In the Chinese translation, when the part of the sentence telling about the bills is moved to the beginning of the sentence, the head-light and end-heavy English sentences also become head-heavy and end-light Chinese sentences, and the thematic pattern is thus changed.

The choice of thematic progression patterns does not simply reflect the correspondence and cohesiveness of language forms, but actually reflects the integration of form and meaning in the dynamic flow of information, and more importantly is deeply influenced by cultural awareness and thinking patterns. The economic discourse is characterized by a large amount of information and complex syntactic realization, and the choice of the thematic progression patterns does matter in the course of expressing, understanding and analyzing their literal meaning, implied message and discourse cohesiveness. From a cross-linguistic perspective, for example, the comparison of English-Chinese thematic progression patterns conducted in this study, grasping the features peculiar to economic discourse, is also of great practical value for learning and translating economic texts.

For further research on the thematic progression, we suggest areas for further efforts:

Firstly, the theoretical construction based on linguistic universals and language-particular features should be further strengthened, and the use of corpus techniques should be explored, and the practical use of theoretical research should be focused on. For example, in the context of Chinese linguistics, for the "imported" nature of the thematic progression theory, it is mainly conducted by the scholars of foreign language studies and the attention to Chinese language facts is far from enough. Our contribution to world linguistic theory is not only to verify or apply a foreign theory, but also to propose and improve it, which must be based on the facts of our native language and combined with a broad cross-linguistic perspective, so future research should strengthen the analysis of the Chinese corpus.

Secondly, interdisciplinary cooperation should be further strengthened to expand research areas and promote the development of artificial intelligence and other construction. In the field of linguistics and literature disciplines, as Figure 1, Figure 2 and Table 1, future related research should continue to focus on linguistics and further strengthen the work more closely related to brain science, such as the acquisition and processing of native and foreign languages. In addition, in the area of interdisciplinary research, also as our literature analysis shows, current research is still largely confined to the areas of language and literature, with a smaller proportion of research findings in law, philosophy, psychology, and computer science. In terms of interdisciplinary research and artificial intelligence, there should be more research in these fields. Also when more scholars specializing computer science and artificial intelligence enter into the field of research, more techniques of data analysis motivated by automated processing of language can invigorate the research in this field swiftly. Some work of great value has been witnessed in these studies, such as Firbas (1971), Pala and Svoboda (2014), Xi et al. (2017, 2019), Ge and Kong (2020).

\section{Acknowledgments}

This study was funded by the project of "Talent Activation Program", Central University of Finance and Economics, and the project of "Cultural Learning, Cultural Confidence and Cultural Promotion: Construction of Curriculum System with Culture and Language as the Carrier", the project of "Teaching Reform of Postgraduate Courses, Central University of Finance and Economics". FAN Li is the principal investigator of the two projects.

\section{References}

Bi, J. F. (2014). Differences in the thematic structures in English and Chinese texts and its implications for translation. University Education, 18, 95-97.

Cao, J., \& Li, Y. R. (2021). Research on the Features of Theme and Thematic Progression Patterns in Online News Discourses. Journal of Tianjin Foreign Studies University, 28(03), 106-116, 161.

Chen, C. (2004). Searching for intellectual turning points: Progressive knowledge domain visualization. PNAS, 101(Suppl. 1), 5303-5310. https://doi.org/10.1073/pnas.0307513100

Chen, Y. (2006). Study of the Theme and Thematic Progression of Acknowledgments. Journal of Zhengzhou Institute of Aeronautical Industry Management (Social Science Edition), 6, 109-111. https://doi.org/10.19327/j.cnki.zuaxb.1009-1750.2006.06.035

Chen, Y. (2011a). A comparative analysis of the thematic progression patterns of medical English papers written 
by Chinese and English authors. Journal of Mudanjiang College of Education, 4, 42-43.

Chen, Y. (2011b). The application of the thematic progression patterns in teaching abstract writing for medical papers. Journal of Guangdong Medical College, 29(03), 339-340.

Daněs, F. (1970). One instance of Prague School methodology: Functional analysis of utterance and text. In Garvin (pp. 132-141). https://doi.org/10.1515/9783110872521.132

Daněs, F. (1974). Functional sentence perspective and the organization of the text. In Papers on Functional Sentence Perspective (pp. 106-128). Mouton, The Hague. https://doi.org/10.1515/9783111676524.106

Deng, J. (2007). On the validity of thematic progress as the unit of E-C translation. Journal of Xihua Normal University (Philosophy and Social Science Edition), 3, 92-96.

Dong, M. (2010). Judicial reasoning with in text-based framework of thematic progression. Journal of Zhejiang Gongshang University, 3, 18-25. https://doi.org/10.14134/j.cnki.cn33-1337/c.2010.03.008

Du, J. (2004). Factors Leading to the Change of Thematic Progression in Translation. Journal of Jiangsu University of Science and Technology (Social Science Edition), 4, 82-86.

Du, J. (2006). The Rhetoric Function of Thematic Progression. Shandong Foreign Language Teaching Journal, 04, 54-58. https://doi.org/10.16482/j.sdwy37-1026.2006.04.013

Firbas, J. (1964). On defining the theme in functional sentence perspective. In Travaux linguistiques de Prague (pp. 1267-1280).

Firbas, J. (1971). On the concept of communicative dynamism in the theory of functional sentence perspective. In $S P F F B U$ (pp. 135-144).

Francis, G. (1990). Theme in Daily Press. Occasional Papers in Systemic Linguistics, 4, 51-87.

Fries, P. H. (1995). Themes, Methods of Development, and Texts. In R. Hasan \& P. H. Fries (Eds.), On Subject and Theme: A Discourse Functional Perspective. Amsterdam: Benjamins. https://doi.org/10.1075/cilt.118.10fri

Guo, Q. (2013). The thematic progression pattern and discourse genre: The example of Obama's inauguration speech. Journal of Jishou University, 34(S1), 103-105.

Hajicovă, E. (1986). Focusing-A Meeting Point Linguistics and Artificial Intelligence (pp. 311-321). In Artificial Intelligence II: Methodology, Systems, Applications, Proceedings of the Second International Conference on Artificial Intelligence: Methodology, Systems, Applications, AIMSA 1986, Varna, Bulgaria, September 16-19.

Halliday, M. A. K. (1967). Notes on Transitivity and Theme in English (Parts 1-3). Journal of Linguistics, 3(1), 37-81. https://doi.org/10.1017/S0022226700012949

Halliday, M. A. K. (1994). An Introduction to Functional Grammar (2nd ed.). London: Edward Arnold.

Halliday, M. A. K., \& Matthiessen, C. (2004). An Introduction to Functional Grammar (3rd ed.). London: Edward Arnold.

Hu, Z. L. (1982). Miscellaneous Foreign Chinese-English Comparative Studies (Part I). Language Teaching and Research, 1, 116-126.

Hu, Z. L. (1984). Halliday's View of Language. Foreign Language Teaching and Research, 1, 23-29.

Hu, Z. L. (1994). Convergence and Coherence in Discourse. Shanghai: Shanghai Education Publishing House.

Huang, G. W. (1988). An Overview of Discourse Analysis (pp. 81-86). Changsha: Hunan Education Press.

Huang, P. (2014). The Analysis of Thematic Progression Pattern in the Introduction Part of Chinese Arbitration Discourses Based on Genre. Foreign Language and Literature, 30(01), 79-82.

Huang, Y. (1985). A preliminary study of theme and rheme in English. Journal of Foreign Languages, 5, 34-38, 20.

Lambrecht, K. (1994). Information structure and sentence form: Topic, focus and the mental representations of discourse referents. Cambridge: Cambridge University Press. https://doi.org/10.1017/CBO9780511620607

Li, G. Q. (2003). The thematic progression pattern and discourse genre: An analysis of The Old Man and the Sea. Foreign Languages and Their Teaching, 7, 53-56.

Li, X. F. (2012). The thematic progression pattern in English financial news discourse. Journal of Jilin Radio 
and TV University, 7, 157-158.

Liu, L. J., Guo, H. J., \& Peng, B. L. (2014). Thematic Choice and Progression in English and Chinese Radio News Reports. Foreign Language Research, 61-68. https://doi.org/10.16263/j.cnki.23-1071/h.2014.05.021.html

Mathesius, V. (1929). Zur Satzperspektive im modernen Englisch. In Archiv fü das Studium der neueren Sprachen und Literaturen (vol. 155, pp. 202-210). Erich Schmidt Verlag.

Nwogu, K., \& Bloor, T. (1991). Thematic Progression in Professional and Popular Medical Texts. In E. Ventola (Ed.), Functional and Systemic Linguistics: Approaches and Uses. Berlin: Fmouton de Gruyter.

Pala, K., \& Svoboda, O. (2014). An Experiment with Theme-Rheme Identification. International Conference on Text, Speech, and Dialogue, Sept. 8, 2014. Springer International Publishing. https://doi.org/10.1007/978-3-319-10816-2_34

Prince, E. F. (1979). On the given/new distinction. In P. R. Clyne, W. F. H. \& C. L. Hofbauer (Eds.), Papers from the fifteenth regional meeting of the Chicago Linguistics Society (pp. 257-278). Chicago: University of Chicago Press.

Prince, E. F. (1981). Toward a taxonomy of given-new information. In C. Peter (Ed.), Radical Pragmatics (pp. 223-255). New York: Academic Press.

Qi, Y. C. (1993). The Prague School and Matthews' Theory of Language. Foreign Languages, 5, 51-56, 12.

Shen, C. (2021). The thematic progression patterns in technical English discourse. English Square, 9, 48-50. https://doi.org/10.16723/j.cnki.yygc.2021.09.016

Shen, W. D. (1999). A study of thematic progression of technical English. Shandong Foreign Language Teaching, 1, 58-61.

Shi, J. S., Naren, T. Y., \& Song, X. (2018). On Thematic Progression in Texts of Stipulated Style- - the Relationship between Thematic Progression, Stylistic Type and the Theme. Applied Linguistics, 1, 90-99. https://doi.org/10.16499/j.cnki.1003-5397.2018.01.014

Wang, M. H. (2009). A comparative analysis of thematic progression patterns in English-Chinese narrative discourse. Journal of Inner Mongolia Nationalities University, 15(03), 49-50.

Wang, X. Y. (2010). A study on the characteristics of the text theme of Chinese economic news text. Journal of Hebei Polytechnic University (Social Science Edition), 10(01), 133-135, 145.

Weng, Y. L. (2011). The contrastive studies of the Thematic/Rhematic Progression in the internal news stylistic. Journal of Northwest University (Philosophy and Social Sciences Edition), 41(06), 146-149.

Xi, X. F., Chu, X. M., Sun, Q. Y., \& Zhou, G. D. (2017). Corpus Construction for Chinese Discourse Topic via Micro-topic Scheme. Journal of Computer Research and Development, 54(08), 1833-1852.

Xi, X. F., Sun, Q. Y., \& Zhou, G. D. (2019). Research and Prospect of Discourse Topic Structure Analysis for Discourse Intentionality. Chinese Journal of Computer, 42(12), 2769-2794.

$\mathrm{Xu}, \mathrm{S} . \mathrm{H}$. (1982). Theme and rheme. Foreign Language Teaching and Research, 1, 1-9.

$\mathrm{Xu}, \mathrm{S}$. H. (1985). Re-discussing theme and rheme. Foreign Language Teaching and Research, 4, 19-25.

Xue, Y. (2007). Characteristic of Thematic Progression Pattern in Business News. Journal of Shandong Agricultural Management Cadre College, 3, 183-184, 186, 194.

Yang, M. (2008). Chinese way of thinking on thematic progression in translation. Journal of Tianjin Foreign Studies University, 5, 1-8.

You, H. (2013). The thematic progression patterns of the English translation of Deng Xiaoping's Selected Writings and its interpersonal function. Journal of Yangtze University (Social Sciences), 36(04), 88-89.

Yu, J. P. (2002). The thematic progression patterns of technological discourse. Chinese Science \& Technology Translators Journal, 2, 3-6, 16. https://doi.org/10.16024/j.cnki.issn1002-0489.2002.02.002.

Zhang, J. X., \& Li, G. Q. (2017). On English Translation of the Stamp Text within the Framework of GSP and Thematic Progression Pattern. Journal of Guangdong University of Foreign Studies, 28(04), 56-61.

Zhang, M. (2005). Variation and Coherence in the pattern of thematic progression in Stream-of-Consciousness Novels. Journal of Xi an International Studies University, 4, 1-3. 
Zhu, Y. S. (1995). Patterns of thematic progression and text analysis. Foreign Language Teaching and Research, $3,6-12,80$.

\section{Copyrights}

Copyright for this article is retained by the author, with first publication rights granted to the journal.

This is an open-access article distributed under the terms and conditions of the Creative Commons Attribution license (http://creativecommons.org/licenses/by/4.0/). 